\title{
PRAWORZĄDNOŚĆ W PERSPEKTYWIE ZASADY PODTRZYMYWANIA ORAZ POGLĘBIANIA KOMUNIKACJI MIĘDZY LUDŹMI
}

\begin{abstract}
Streszczenie. W artykule poruszono problematykę praworządności w znaczeniu szerszym i węższym, odnosząc się do koncepcji moralności prawa L.L. Fullera. Postawiono także kwestię związku między formalnymi wymogami praworządności a zasadą podtrzymywania oraz pogłębiania komunikacji między ludźmi.
\end{abstract}

Słowa kluczowe: zewnętrzna moralność prawa, wewnętrzna moralność prawa, praworządność, prawo naturalne, warunki akceptowalności prawa, komunikacja między ludźmi, Fuller.

Z etycznego punktu widzenia pluralistyczna forma humanizmu jest dla mnie, w porównaniu z jakąkolwiek inną filozofią, najbliższa rzeczywistości. Jest to z istoty swej spoleczna filozofia, w której słówko „współ” gra ważną rolę.

William James (James 1973, 185)

\section{UWAGI WPROWADZAJACEE}

Jak sprecyzować pojęcie praworządności? Czy pojęcie to zyskuje pożądany wyraz, jeśli zarysowywać je w perspektywie etycznej? Czy formalny postulat praworządności domaga się wyraźnego materialnego kontekstu, który zasadniczo można odczytać jako dopełnienie wymogu formalnego? Klasyczna dziś koncepcja Lona L. Fullera, ukształtowana na fali powojennego odrodzenia prawa natury (Tokarczyk 1999, 308), podsuwa interesujący pryzmat rozważenia tej kwestii, nie dość wyzyskany w literaturze przedmiotu, skupionej na proceduralnym aspekcie tworzenia i stosowania dobrego prawa jako najistotniejszym legacie w dorobku Fullera, zapisanym przez niego filozofii prawa. Myśl Fullera jest zatem najczęściej identyfikowana jako badająca formalne aspekty prawa ${ }^{1}$ (Krygier 2011, 6). Fuller jednak czyni więcej. Jego koncepcja dziś staje się interesująca właśnie dzięki

* Uniwersytet Warszawski, Wydział Prawa i Administracji, Katedra Filozofii Prawa i Nauki o Państwie, ania.rossmanith@gmail.com.

${ }^{1}$ M. Krygier sytuuje ją wśród filozoficznych koncepcji zaabsorbowanych analizowaniem formalnych cech definiujących samo zjawisko prawa. 
dopełniającej formalne określenie prawa zasadzie podtrzymywania oraz pogłębiania komunikacji między ludźmi, która ma charakter zewnętrznego prawa naturalnego, zakotwiczonego w filozofii człowieka. Głównym zadaniem niniejszego artykułu jest rozważenie, jaki wpływ może mieć ta zasada na istnienie formalnych wymogów praworządności.

Stosowanie przez Fullera terminologii prawnonaturalnej jest podyktowane chęcią usytuowania jego koncepcji wśród kierunków krytycznie nastawionych do pozytywizmu, podważających tezę o rozdziale prawa i moralności. Wydaje się więc, że prawnonaturalne podejście Fullera należy odczytywać przede wszystkim poprzez pryzmat jego generalnej tezy, głoszącej, że o pojęciu prawa decyduje pewna specjalnie rozumiana moralność, wykluczająca traktowanie prawa jako „,jednostronnej projekcji władzy” narzucającej się obywatelowi. Jak słusznie zauważa Kristen Rundle, wyznaczone przez Fullera warunki akceptowania prawa - conditions of law's acceptance - mają swój podwójny sens (Rundle 2013, 63), ufundowany na zasadniczym prawnonaturalnym poglądzie Fullera, że prawo nie może być zbudowane na prawie - law cannot be built on law (Fuller 1958, 645). $Z$ jednej strony ów sens ujawnia się właśnie w postaci zewnętrznej moralności prawa, z drugiej - w postaci wewnętrznej moralności prawa.

\section{FILOZOFICZNE PODSTAWY STANOWISKA LONA L. FULLERA}

W ujęciu Fullera rzeczywistość społeczno-polityczna ma przede wszystkim wymiar praktyczny. Właśnie uczynienie z pragmatyzmu odniesienia do badań nad stosunkiem między prawem a moralnością nadaje filozofii Fullera swoisty charakter. Pragmatyzm interesuje się bowiem praktyką ludzkiego jednostkowego życia, poszukiwaniem tego, co skutecznie może zapewnić dobre życie. Przejawiana przez pragmatystów niechęć do klasycznej koncepcji prawdy mającej Arystotelesowskie źródła bierze się właśnie stąd, że rzeczywistość pojmują nie jako byt obiektywny, lecz jako wytwór ludzkiej aktywności².

Jednym z istotnych powodów, który czyni z Fullera badacza prawa myślącego filozoficznie, jest dociekanie kwestii z pozoru oczywistych. Szukając warunków brzegowych pojęcia prawa, Fuller wydobywa i analizuje te cechy prawa, które prima facie wydają się banalne.

Z pewnego punktu widzenia nie jest bynajmniej rzeczą szczęśliwą, iż wymogi moralności prawa wydają się tak oczywiste. Przesłaniało to często subtelności i skłaniało ludzi

${ }^{2}$ Według klasycznej definicji prawda jest związkiem między naszym umysłem a obiektywnie rozumianą rzeczywistością, to znaczy istniejącą niezależnie od ludzkiej świadomości: Veritas est adaequatio rei et intellectus. Na gruncie pragmatyzmu przyjmuje się jednak, że prawda ma charakter koherencyjny. Prawdę wytwarzamy w naszym doświadczeniu. Oczywiście rewizja sensu prawdy nie była kwestią zrodzoną wyłącznie na gruncie filozofii pragmatycznej. Natomiast specyficznie pragmatyczne jest przypisywanie temu, co prawdziwe konsekwencji praktycznych. 
do przekonania, iż żadna szczegółowa analiza tej kwestii nie jest ani potrzebna, ani nawet możliwa (Fuller 1978, 145).

Jednak dogłębniejsze analizowanie wątków oczywistych czy samozrozumiałych, obce myśleniu trywialnemu, potocznemu, bywa niezwykle płodne filozoficznie. Potrzebne jest bowiem uzasadnienie, które poszerza horyzont i wiąże rzecz błahą z rzeczą odkrywczą. Na pragnieniu tym zasadza się każde wyjście z Platońskiej jaskini, dociekające źródła cieni i porzucające jednokierunkowość łatwego spojrzenia.

Z myśli Fullera wyłania się głębokie przeświadczenie, że pogląd na człowieka leżący u podstaw prawa nie jest ani bagatelny, ani obojętny. To w jego świetle prawo powinno być odczytywane. Filozofia człowieka wobec tego nie jest przez Fullera zakładana milcząco.

Najważniejszym aspektem przestrzegania wymogów moralności prawa jest służba „celom ludzkiego życia w ogólności”. Fuller zdaje się twierdzić, że wewnętrzna moralność prawa chroni przed jego zinstrumentalizowaniem. Tę ochronę zapewnia pogląd na człowieka zawarty w wewnętrznej moralności prawa.

Wielokrotnie powtarzałem, iż moralność prawa jest neutralna w odniesieniu do szerokiego zakresu problemów etycznych. Lecz nie może ona być neutralna wobec człowieka jako takiego. Podjęcie działalności, mającej na celu podporządkowanie ludzkiego zachowania zasadom, pociąga za sobą z konieczności akceptację poglądu, iż człowiek jest lub stać się może podmiotem odpowiedzialnym (Fuller 1978, 218).

Uchybienie zasadom wewnętrznej moralności prawa jest pogwałceniem godności człowieka jako podmiotu odpowiedzialnego, m.in. sądzenie jego czynów na podstawie praw nieogłoszonych lub działających z mocą wsteczną gwałci godność człowieka jako samodzielnego i samookreślającego się podmiotu. Działalność prawodawcy kreującego takie prawo lub sędziego je stosującego wyraża $\mathrm{w}$ gruncie rzeczy podejście, które zezwala na manipulowanie człowiekiem i uprzedmiotawianie go. Taka postawa myślowa jest antyfilozoficzna i antypraw$\mathrm{na}^{3}$. Cała nasza cywilizacja oparta jest na przekonaniu, że człowiek może kierować swoim zachowaniem, a prawo jest porządkiem wymagającym świadomych twórców i odbiorców.

Świadome istnienie jest zawsze związane z wymiarem moralnym. Bez tego wymiaru nie ma człowieczeństwa. Prawo, stosując się do życia społecznego,

${ }^{3}$ Używając tych określeń, odwołuję się do tytułu glosy Jerzego Zajadło (Zajadło 2008, 179194). Glosa dotyczyła uchwały SN z dnia 20 grudnia 2007 r., wpisanej do księgi zasad prawnych, stwierdzającej, że „sądy orzekające w sprawach karnych o przestępstwa z dekretu Rady Państwa z dnia 12 grudnia 1981 r. o stanie wojennym (Dz.U. Nr 29, poz. 154) nie były zwolnione z obowiązku stosowania retroaktywnych przepisów karnych rangi ustawowej” (I KZP 37/2007). Autor odnosi słowa ,antyfilozofia antyprawa” do uzasadnienia legalności orzecznictwa, naruszającego zasadę lex severior retro non agit, a w konsekwencji także nullum crimen, nulla poena sine lege poenali anteriori. 
powinno traktować odniesienie do świadomego istnienia jako swój warunek brzegowy.

Fuller podkreśla dwustronność, niemal partnerskość relacji między obywatelem a instytucjami tworzącymi prawo oraz instytucjami je stosującymi. Bowiem to od odpowiedzialnego podmiotu zależy w znacznej mierze funkcjonowanie prawa. Prawo traktowane jako ,jednostronna projekcja władzy, emanująca z uprawnionego źródła i narzucająca się obywatelowi” jest specjalnością analitycznego pozytywizmu - kwituje (Fuller 1978, 252). Odejście od pozytywizmu ma na gruncie koncepcji moralności prawa oznaczać wzmocnienie dwustronności relacji między obywatelem a instytucjami. Według Fullera pozytywizm odrzuca fundamentalny element tworzenia systemu prawnego, którym jest współdziałanie prawodawcy i obywatela (Fuller 1978, 252).

Rzeczą ciekawą z filozoficzno-prawnego punktu widzenia jest umiejscowienie proceduralnej koncepcji prawa natury wśród wielu różnych typów koncepcji prawnonaturalnych. Przede wszystkim istotne jest przyjęte kryterium (a tych może być kilka) ${ }^{4}$, za sprawą którego klasyfikujemy określony typ koncepcji. Ze względu na źródło pochodzenia prawa koncepcję tę można sytuować wśród wskazujących na rozum lub godność człowieka, choć inaczej pojętą niż w dynamicznej teorii prawa natury. Do rozumu jako źródła odwołują się koncepcje teoriopoznawcze. Różnica między tradycyjnymi koncepcjami prawnonaturalnymi a koncepcjami teoriopoznawczymi jest ogromna. Stanowisko Fullera z pewnością nie stanowi powrotu do tradycyjnych teorii prawnonaturalnych. Jest natomiast konsekwencją przyjęcia pragmatyzmu jako podstawy filozoficznej.

\section{MORALNOŚĆ DĄŻEŃ - MORALNOŚĆ OBOWIĄZKU}

Przeprowadzone przez Fullera rozróżnienie na moralność dążeń i moralność obowiązku jest zakorzenione w starożytnej filozofii greckiej. Rozróżnienie to staje się szczególnie pomocne, gdy podejmowana jest problematyka stosunku prawa do moralności (Fuller 1978, 34). Fuller uważa, że trudność z ustaleniem tej relacji wynika przede wszystkim z braku dokonanego przez prawników należytego rozeznania, czym jest moralność. Oryginalność refleksji Fullera polega przede wszystkim na dostrzeżeniu konsekwencji tego rozróżnienia dla prawa.

Moralność obowiązku ma charakter minimalistyczny, formułuje ,zasadnicze reguły, bez których niemożliwe jest w ogóle istnienie uporządkowanego społeczeństwa" (Fuller 1978, 36).

Moralność dążeń ma charakter perfekcjonistyczny. W odniesieniu do niej kluczowym myślicielem był Sokrates, który nadał greckiemu pojęciu duszy profil etyczny. Psyché stanowiła to, co w nas najbardziej boskie i wiązała się z pojęciem

\footnotetext{
${ }^{4}$ Na temat kryteriów i klasyfikacji zob. np. M. Szyszkowska (2008, 36-48).
} 
cnoty (areté), rozumianej jako doskonałość etyczna. Człowiek w świetle Sokratejskiej metody nauczania jest uzdolniony do rozwijania tej doskonałości. Obszar kultury stanowi domenę moralności dążeń. Jednym z najważniejszych jej powołań jest ochrona i wzbogacanie społecznego dziedzictwa języka, myśli i sztuki (Fuller 1978, 44).

\section{PRAWORZĄDNOŚĆ W ZNACZENIU SZERSZYM}

Praworządność w znaczeniu formalnym (inaczej wewnętrzna moralność prawa, czy też proceduralne prawo natury) jest zespołem wymogów, które dopiero łącznie potraktowane warunkują władzę prawa. Stają się gruntem suwerenności prawa. Określone zostały przez Fullera jako wewnętrzne, aby uwypuklić ich zawieranie się już w samym pojęciu czy istocie prawa. Natomiast o ich moralnym charakterze (moralności) świadczy to, że dostarczają standardów oceny prawa (Lyons 2000, 72). Fuller pisze o nich, że są „,moralnością, bez której prawo jest niemożliwe" (Fuller 1978, 34). Analiza zabawnych - na pierwszy rzut oka - przypadków króla Rexa, przedłożonych naszej uwadze, prowadzić ma do precyzyjnych wniosków na temat rządów prawa, których podstawowym zadaniem jest ochrona poddanych przed samowolą władcy i traktowaniem przez niego prawa jako doraźnego przedłużania jego władzy. Warto wobec tego przeanalizować osiem wymogów referowanych przez Fullera jako warunki brzegowe pojęcia prawa, a nawet jako wpisane w pojęcie prawa zasady sprawiedliwości. W świetle moralności aspiracji można je ocenić jako pożądane cechy czy atrybuty prawa, które osiągają różne poziomy doskonałości. Są nimi:

1) Ogólność. Istotny aspekt bezstronności.

2) Promulgacja.

3) Prospektywność.

4) Jasność.

5) Niesprzeczność.

6) Możliwość realizacji.

7) Stabilność.

8) Zgodność między działaniem instytucji a obowiązującym prawem.

Ten ostatni warunek jest także określany mianem praworządności w węższym sensie, czy też praworządności w procesie stosowania prawa.

Z pewnością respektując wymogi wewnętrznej moralności prawa, można uniknąć wielu postaci niesprawiedliwości (Lyons 2000, 72). Ponadto zrealizowanie tych postulatów czyni prawo skutecznym, co wiąże się z pragmatycznym pojęciem dobra. Wymogi praworządności, posiadając moralny charakter ${ }^{5}$, stanowią

${ }^{5} \mathrm{~W}$ przeciwieństwie do L.L. Fullera moralnego charakteru odmawia im np. M.H. Kramer (1999, 37-77). Inaczej H.L.A. Hart, który uważa, że „dystynkcja między dobrym systemem prawa, 
przejaw moralności aspiracji i wyznaczają swoisty krwiobieg prawa. Herbert L.A. Hart podchodzi do tej kwestii o wiele ostrożniej, ale dostrzega, że standardy proceduralne, nawet w swej najbardziej elementarnej formie sprawiedliwości w stosowaniu prawa, rzeczywiście zawierają ,zarodek sprawiedliwości już w samym pojęciu stosowania ogólnego przepisu prawa" (Hart 1998, 277-278). Jednak Hart nie ma wątpliwości, że „najbardziej niegodziwe prawa mogą być sprawiedliwie stosowane"6 (Hart 1998, 278). Proceduralne wymogi stawiane prawu pozostają dla niego jedynie elementami kontroli społecznej.

Tymczasem Fuller rozszerza swoją refleksję o zagadnienie, budzące zainteresowanie wielu filozofów i teoretyków prawa, ewentualnej niewystarczalności zasad praworządności formalnej. Stosując paralelę, zadaje pytanie, czy cieśla, dysponujący odpowiednim warsztatem pracy, mógłby równie dobrze budować sierocińce, jak i szubienice? (Notabene paralela nie jest najszczęśliwsza, ponieważ traktuje warsztat pracy prawnika na podobieństwo warsztatu rzemieślnika). Innymi słowy, czy istnieje pokrewieństwo między praworządnością formalną a sprawiedliwością? Niespełnienie warunków wewnętrznej moralności prawa z pewnością prowadzi do bezprawia, ale czy ich spełnienie gwarantuje dobre prawo? Zagadnienie to nurtowało Fullera już od lat czterdziestych XX wieku, kiedy rozważał, czy prawo nazistowskie rzeczywiście mogło być nazywane prawem (za Widłak 2016, 113)7. Już wtedy odwołał się do uzasadnienia zawartego w artykule z 1958 r. Positivism and Fidelity, będącym odpowiedzią na stanowisko Harta odnoszące się do rozdziału prawa i moralności, w którym wprowadził pojęcie moralności zewnętrznej w stosunku do prawa (morality external to law). Mianowicie - można podważyć prawny charakter ustaw nazistowskich, wskazując, że nie tylko nie stwarzały, ale burzyły warunki normalnej obywatelskiej koegzystencji (Eskridge 1993, 1737-1738). Sugeruje to wyraźne odwołanie do filozoficznych podstaw Fullerowskiej koncepcji moralności prawa ze szczególnym uwzględnieniem zewnętrznego jej sensu.

\section{PRAWORZĄDNOŚĆ W PROCESIE STOSOWANIA PRAWA}

Wśród postulatów wewnętrznej moralności prawa szczególne miejsce zajmuje postulat zgodności działań podejmowanych przez organy władzy publicznej z obowiązującymi regułami prawnymi. W ramach tego postulatu Fuller sytuuje

\footnotetext{
zgodnym w pewnych punktach z moralnością i sprawiedliwością, a takim, który nie jest z nimi zgodny, jest błędna" (Hart 1998, 277).

${ }^{6}$ Trzeba jednak zauważyć, że Fuller zarzucał przeprowadzonym przez Harta analizom niedostrzeżenie stopnia, w jakim naziści lekceważyli wewnętrzną moralność prawa, argumentując, że na fundamentalnym poziomie zostało zanegowane to, co podmiot prawny powinien móc oczekiwać od prawa (Rundle 2013, 68-69).

${ }^{7}$ Zob. W.N. Eskridge (1993, 1737-1738).
} 
problematykę niezależności urzędu sędziowskiego, utrzymanie instytucji prawnych w harmonii, a nade wszystko zagadnienie wykładni. Zgodność działania instytucji państwa z prawem - jak pisze Fuller - może zostać naruszona lub podważona na wiele sposobów, np. poprzez błędną interpretację, „,brak względu na to, co niezbędne dla utrzymania integralności systemu prawnego”, „dążenie do władzy osobistej" (Fuller 1978, 125). Zadanie zapobiegania tym nieprawidłowościom spoczywa m.in. na sądownictwie. Jako zwolennik intencjonalizmu w sporze o wykładnię prawa, chcąc zapobiec wadliwej interpretacji konstytucji, kulminującej w stwarzaniu arbitralnego obrazu stosunków między normami konstytucyjnymi a ich realizacją w praktyce, koncentruje się na dociekaniu ,jakie środki mogą być podjęte, by utrzymać sądową interpretację aktów prawnych w zgodności z intencją wyrażoną w tych aktach" (Fuller 1993, 33). Przyjmując perspektywę moralności dążeń, praworządność wyznacza ideał państwa prawnego, a zatem ma charakter stopniowalny, dając podstawę do krytycznej oceny konkretnej władzy ${ }^{8}$.

\section{PRAWNONATURALNY WYMÓG O CHARAKTERZE MATERIALNYM}

Czy z moralności dążeń można wyprowadzić coś bardziej kategorycznego niż tylko wezwanie do doskonałości? - pyta Fuller.

Już sama wewnętrzna moralność prawa stanowi odmianę prawa natury, określoną przez niego jako proceduralna, czy też instytucjonalna. Ale właśnie to proceduralne, czy instytucjonalne prawo natury wpływa na materialne cele, jakie mogą być przez prawo osiągane (Fuller 1978, 243). Ograniczenie pojęcia prawa przez wyznaczenie jego warunków brzegowych ma wagę nie tylko dlatego, że służy różnym wartościowym celom, ale dlatego, że można zbadać źródło takiego ujmowania prawa i wysunąć ogólniejsze wnioski zeń płynące.

Analizując kwestię materialnego prawa natury, Fuller odnosi się do wątków minimalnej treści prawa naturalnego - wpływowego komponentu miękkopozytywistycznej koncepcji prawa Herberta L.A. Harta. Wychodzi od, wskazanego przez swojego brytyjskiego oponenta, uniwersalnego celu gatunku ludzkiego, jakim jest jego biologiczne przetrwanie ${ }^{9}$ (Hart 1998, 261-269). Hart zwraca uwagę, że porządek społeczny, potrzebny do trwałej egzystencji, wymaga przyjęcia tego skromnego, ale ważnego minimum, uzasadnionego przez zespół twierdzeń, określonych przez autora jako truizmy wiążące się z naturą ludzką. Fuller jednak trafnie wychwycił, że są one niczym innym jak tylko pewnego rodzaju minimum moralności obowiązków (Fuller 1978, 244). Nietrudno dostrzec,

${ }^{8}$ Zob. na temat krytycznej oceny władzy z perspektywy wymogów praworządności: m.in. L. Godek, M. Sikora $(2017,13)$.

${ }^{9}$ Prawo powinno zawierać szczególną treść, bez której „nie mogłoby służyć minimalnemu celowi przetrwania, realizowanemu przez człowieka, gdy wchodzi w związki społeczne" (Hart 1998, 261). 
że uwaga twórcy Moralności prawa szybuje wyżej: w stronę moralności dążeń. Zanim jednak Fuller to uczyni, przystępuje do analizy przetrwania jako postulowanego przez Harta wstępnego warunku wszelkiego innego ludzkiego dobra. Zgadzając się z tą tezą, zwraca jednak uwagę, że Hart przenosi ją na zgoła nierudymentarny poziom. Czy biologiczne przetrwanie rzeczywiście jest sensem prawa naturalnego i całej myśli moralnej? Czy wyznacza sedno ludzkich dążeń? Otóż według Fullera Hart popełnia błąd, stawiając przetrwanie ponad poziomem moralności obowiązku. Człowiek aspiruje do tego, co nadaje sens jego ludzkim wysiłkom. Fuller zatem wysuwa zupełnie inną niż Hart cząstkę ludzkich dążeń jako „zasadę podtrzymującą i przenikającą wszelkie ludzkie aspiracje”, mianowicie: łączność z drugim człowiekiem. Idąc tropem Harta, Fuller argumentuje, że „ludzie potrafili dotąd utrzymać się przy życiu dzięki zdolności do komunikowania się". Jedną z istotniejszych korzyści komunikowania się - pisze Fuller - jest gromadzenie i przekazywanie wiedzy oraz świadome i przemyślane koordynowanie wysiłku z innymi ludźmi (Fuller 1978, 245). Co więcej: ,jeśli w przyszłości człowiek potrafi poskromić swe tendencje do samozagłady, stanie się to dzięki temu, że może się on komunikować i porozumiewać z bliźnimi" (Fuller 1978, 245). Jednocześnie Fuller uprzedza ewentualną krytykę, która miałaby polegać na potraktowaniu sensownego kontaktu z drugim człowiekiem jako środka do utrzymania się przy życiu. Porozumiewanie się jest czymś znacznie więcej. Dotyka granic naszego życia. Kumuluje zdobycze ludzkiego wysiłku. Włącza nas w społeczne dziedzictwo myśli i sztuki. Decyduje o tym, że nieustannie przekraczamy biologiczną egzystencję. „Jednym z najważniejszych powołań moralności dążeń jest ochrona i wzbogacanie tego społecznego dziedzictwa" (Fuller 1978, 44).

Zatem jeśliby wyróżnić ,jedną, główną, niezakwestionowaną” zasadę materialnego prawa natury, dopełniającego treściowo proceduralne wymogi stawiane prawu, to jej treścią byłoby wezwanie do porozumienia, do międzyludzkiej komunikacji. Fuller formułuje ją następująco: „,rozszerzaj, utrzymuj i zachowuj integralność kanałów porozumiewania się, za których pośrednictwem człowiek przekazać może bliźniemu, co postrzega, odczuwa i czego pragnie" (Fuller 1978, 246).

Przy czym należy wziąć pod uwagę, że nie chodzi o tworzenie prawa w procedurze komunikacyjnej. Fuller wyraźnie podkreśla konieczność nadania treści prawa zabarwienia komunikacyjnego.

\section{REŻIM GRANATOWYCH KOSZUL - INTERREGNUM SUWERENNOŚCI PRAWA. ANALIZA PRZYPADKU}

W jaki sposób tzw. dobre prawo, tzn. respektujące wymogi moralności wewnętrznej i zewnętrznej, może zostać odniesione do okresu interregnum swojej suwerenności? 
Fuller kreśli obraz „złych czasów”, które nastały w kraju cieszącym się dotychczas ,pokojowymi, konstytucyjnymi i demokratycznymi rządami” (Fuller 1978, 311). Poza niewątpliwym złem wyrządzonym przez kwestionowanie, a właściwie niestosowanie konstytucji, zwłaszcza w obszarze konstytucyjnych ograniczeń władzy politycznej, dzieleniu społeczeństwa na tych, którzy popierają Granatowe Koszule i w związku z tym liczyć mogą na specjalne traktowanie oraz opozycjonistów, którzy nie doczekają się ochrony swoich praw, po reżimie pozostaje realny problem rozliczenia jego niegodziwości i zbrodni. Powstaje wobec tego pytanie, jak zestroić zagadnienie moralności prawa z rozliczeniem władzy łamiącej praworządność oraz obywateli wyprzedzająco wobec tej władzy posłusznych, zwłaszcza tzw. donosicieli.

Fuller referuje pięć możliwych reakcji na tę sytuację:

1) Nie ma możliwości rozliczenia, ponieważ władza nie tyle działała bezprawnie, co podporządkowana była określonej ideologii, polegającej na „,narzucaniu wszystkim swojego monolitycznego poglądu” (Fuller 1978, 314). Rządziły kłamstwa i naginanie prawa.

2) Nie należy rozliczać, ponieważ miniona forma nie stanowiła praworządnego ustroju tylko władzę terroru. „Musimy zapomnieć o tym całym ponurym okresie bezprawia w naszej historii jak o złym śnie" (Fuller 1978, 316).

3) Trzeba interweniować w konkretnych przypadkach.

4) Należy stworzyć specjalną ustawę ex post facto.

5) Należy przymknąć oko na samosądy.

Pierwsze i drugie stanowisko wydaje się być dość typową bezradną reakcją demokratycznego państwa prawnego na ustrój niedemokratyczny lub okres zapaści rządów prawa. Czwarte i piąte, w świetle koncepcji moralności prawa, jest niedopuszczalne. Natomiast trzecie stanowisko - najbardziej wyważone - głosi, że nie wszystko, co zaszło za czasów Granatowych Koszul było bezprawne, jednak z pewnością da się stwierdzić przypadki łamania prawa: absurdem byłoby nieuwzględnienie bezprawnych działań tylko dlatego, że ,przeprowadzane były za pośrednictwem aparatu państwowego, który stał się w gruncie rzeczy alter ego Partii Koszul" (Fuller 1978, 317). Istnienie kłopotliwych przypadków nie może przekreślić stosowania obowiązującego prawa.

\section{WNIOSKI}

Wymóg wewnętrznej i zewnętrznej moralności prawa orientuje prawników (sędziów) filozoficznie. Wewnętrzna moralność prawa jest swoistym abecadłem rzemiosła prawnego, ale zarazem proceduralną odmianą prawa natury, czy też inaczej - wyrazem moralności dążeń. Określając swoją koncepcję mianem moralności prawa, Fuller nie tylko czyni uwagę o charakterze porządkującym i sytuującym tę koncepcję w takiej czy innej klasyfikacji, ale traktuje wymogi moralności 
prawa jako prawo natury. O moralności prawa - w kompletnym sensie - można mówić wtedy, kiedy zachowane są zarówno proceduralnie ujęte wymogi stawiane prawu, jak i spełniona jest zasada podtrzymywania i pogłębiania komunikacji między ludźmi.

Pisząc o tym, iż dobre prawo wymaga od obywateli poczucia uczestnictwa, Fuller trąca chyba najbardziej istotne struny tego, co określa moralnością prawa. Rozdzielenie prawa i moralności oznacza w istocie odcięcie człowieka od tego, co jest dla niego naprawdę ważne. Dokonując takiego rozdzielenia, odmawia się przyznania prawu kompetencji, której ono się domaga.

\section{BIBLIOGRAFIA}

Eskridge, William N. Jr. 1993. „The Case of the Speluncean Explorers: Twientieth-Century Statutory Interpretation in a Nutshell". The George Washington Law Review 6 (61): 1731-1753.

Fuller, Lon L. 1958. „Positivism and Fidelity to Law: A Replay to Professor Hart”. Harvard Law Review 4 (71): 630-672.

Fuller, Lon L. 1978. Moralność prawa. Tł. Stefan Amsterdamski. Warszawa: Państwowy Instytut Wydawniczy.

Fuller, Lon L. 1993. Anatomia prawa. Tł. Roman Tokarczyk. Lublin: Instytut Wydawniczy Daimonion.

Godek, Lidia. Sikora, Marek. 2017. „O praworządności i demokracji. Zarys problemu”. Filo-Sofija 1-2: 9-15.

Hart, Herbert L.A. 1998. Pojęcie prawa. Tł. Jan Woleński, Warszawa: Wydawnictwo Naukowe PWN

James, William. 1973. „Istota humanizmu”. Tł. Hanna Buczyńska-Garewicz. W Hanna Buczyńska-Garewicz. James. 183-190. Warszawa: Wiedza Powszechna (pierwodruk: James, William. 1905. „The Essence of Humanism”. Journal of Philosophy, Psychology and Scientific Methods 5: 113-118).

Kramer, Matthew Henry. 1999. In Defense of Legal Positivism. Law Without Trimmings. Oxford: Oxford University Press.

Krygier, Martin. 2011. „Cztery pytania o rządy prawa: Dlaczego? Co? Gdzie? I kogo to obchodzi?”. Tł. Katarzyna Mikołajczyk-Graj. Archiwum Filozofii Prawa i Filozofii Społecznej 2: 5-19.

Lyons, David. 2000. Etyka i rzady prawa. Tł. Paweł Maciejko. Warszawa: Dom Wydawniczy ABC.

Rundle, Kristen. 2013. Forms Liberate. Reclaiming the Jurisprudence of Lon L. Fuller. Oxford and Portland: Hart Publishing.

Szyszkowska, Maria. 2008. Teoria i filozofia prawa. Warszawa: Dom Wydawniczy ELIPSA.

Tokarczyk, Roman. 1999. Historia filozofii prawa w retrospektywie prawa natury. Białystok: Temida 2 .

Widłak, Tomasz. 2016. Fuller. Sopot: Arche.

Zajadło, Jerzy. 2008. „Pięć minut antyfilozofii antyprawa”. W Po co prawnikom filozofia prawa? 179-194. Warszawa: Wolters Kluwer. 


\title{
Anna Rossmanith
}

\section{THE RULE OF LAW IN THE PERSPECTIVE OF THE PRINCIPLE OF MAINTAINING AND DEEPENING COMMUNICATION BETWEEN PEOPLE}

\begin{abstract}
The article deals with the issue of the rule of law in a broader and narrower sense, with reference to L.L. Fuller's concept of the morality of law. The article also raises the question of the connection between formal requirements of the rule of law and the principle of maintaining and deepening communication between people.

Keywords: external morality of law, internal morality of law, rule of law, natural law, conditions of law's acceptance, communication between people, Fuller.
\end{abstract}

